\title{
Autoimmune haemolytic anaemia associated with ovarian dermoid cyst
}

\author{
L. R. I. BAKER, M. C. BRAIN, J. G. AZZOPARDI, AND S. M. WORLLEDGE \\ From the Departments of Haematology, Medicine, and Morbid Anatomy, \\ Royal Postgraduate Medical School, London
}

SYNOPSIS A case of autoimmune haemolytic anaemia is described in which recovery, with disap-i pearance of antibody, followed splenectomy and removal of an ovarian 'dermoid' cyst. A causaler relationship between removal of the ovarian tumour and recovery is strongly suggested and the possible pathogenesis discussed. Fourteen previously recorded cases of this association are reviewed.

Since the first description (West-Watson and Young, 1938) 13 further cases of haemolytic anaemia associated with benign cystic teratomata ('dermoid' cysts) of the ovary have been described. A causal relationship between the ovarian tumour and haemolysis in these cases is strongly suggested by the fact that, with the exception of two cases in which the patient died before operation (de Gruchy, 1954) or at operation (Lindeboom, 1950), cessation of haemolysis invariably followed removal of the ovarian tumour. Autoantibodies were found in nine of the 11 patients in this series in whom a specific search was undertaken.

A further patient is described here in whom haemolysis ceased following the removal of an ovarian 'dermoid' cyst and in whom it has been possible to follow the rate of disappearance of autoantibody since operation.

\section{CASE REPORT}

A 52-year-old housewife was referred to the care of Professor J. V. Dacie at Hammersmith Hospital by Dr E. C. B. Keat (Royal Sussex County Hospital) on 16 September 1966. She complained of increasing tiredness and exertional dyspnoea for the previous nine months. The diagnosis of autoimmune haemolytic anaemia had been established and she had received prednisone, $40 \mathrm{mg}$ daily, since the beginning of September without response.

Neither she, her parents, nor her two children had ever been anaemic or jaundiced in the past. For two years her periods had been irregular and somewhat scanty. There was no history of pelvic pain or vaginal discharge.

On examination, she was pale and slightly icteric. No mass was felt in the abdomen and the liver and spleen were not palpable. Routine rectal and pelvic examinations $\mathbb{D}$ were unrevealing. Respiratory, cardiovascular, and $\frac{\vec{\Phi}}{\Phi}$ central nervous systems were normal.

INVESTIGATIONS Haemoglobin was $6.8 \mathrm{~g}$ per $100 \mathrm{ml}$, PCV $19 \%$, reticulocytes $11 \%$, platelets 126,000 perc cu mm, total white cell count 12,000 per cu mm (neutro-ळ phils 9,240 per cu mm, lymphocytes 2,280 per cu mm, monocytes 480 per cu $\mathrm{mm}$ ). The peripheral blood filmo showed well-marked spherocytosis and polychromasia of red cells. Sternal marrow showed erythroid hyper-ō plasia, consistent with active haemolysis.

The direct Coombs test was strongly positive, the red® cells being agglutinated by anti-IgG serum but not by $\overrightarrow{\vec{\sigma}}$ an anticomplement serum. The antibody was readily eluted from red cells; both this and free antibody detected in her serum showed anti-e Rhesus specificity.

The serum bilirubin was $2.0 \mathrm{mg}$ per $100 \mathrm{ml}$ and the plasma haemoglobin was $22.8 \mathrm{mg}$ per $100 \mathrm{ml}$ (normalo $0-2 \mathrm{mg}$ per $100 \mathrm{ml}$ ). Serum alkaline phosphatase was:5 King-Armstrong units. Serum albumin was $5.3 \mathrm{~g}$ per 3 . $100 \mathrm{ml}$ and serum globulin was $2 \cdot 2 \mathrm{~g}$ per $100 \mathrm{ml}$. The serum electrophoretic pattern showed no abnormality. $\frac{\text { 을 }}{3}$ The urine contained large amounts of haemosiderin. There was no evidence of occult blood in the stools.

The survival of the patient's red cells was estimated $>$ using ${ }^{51} \mathrm{Cr}$-labelled red cells. ${ }^{51} \mathrm{Cr}$-red cell half-life was을 five days (normal 25 to 32 days). There was no preferential uptake of red cells by the spleen, as shown by surface? counting.

The haemoglobin level fell despite treatment withN prednisone, $40 \mathrm{mg}$ daily, and five days after admission ${ }_{\sigma}^{\omega}$ the dose was doubled. She did not respond, and on the tenth day of admission she was transfused with 40 units of packed cells, and ACTH, 90 iu intravenously $\bar{\Phi}$ daily, was added to the régime at this time. Again, no? response occurred. On the 32nd day of her admission 0 the patient developed a left hemiparesis and upper motorō neurone left facial palsy. She again needed transfusion and it was decided to proceed to splenectomy, in spite of 


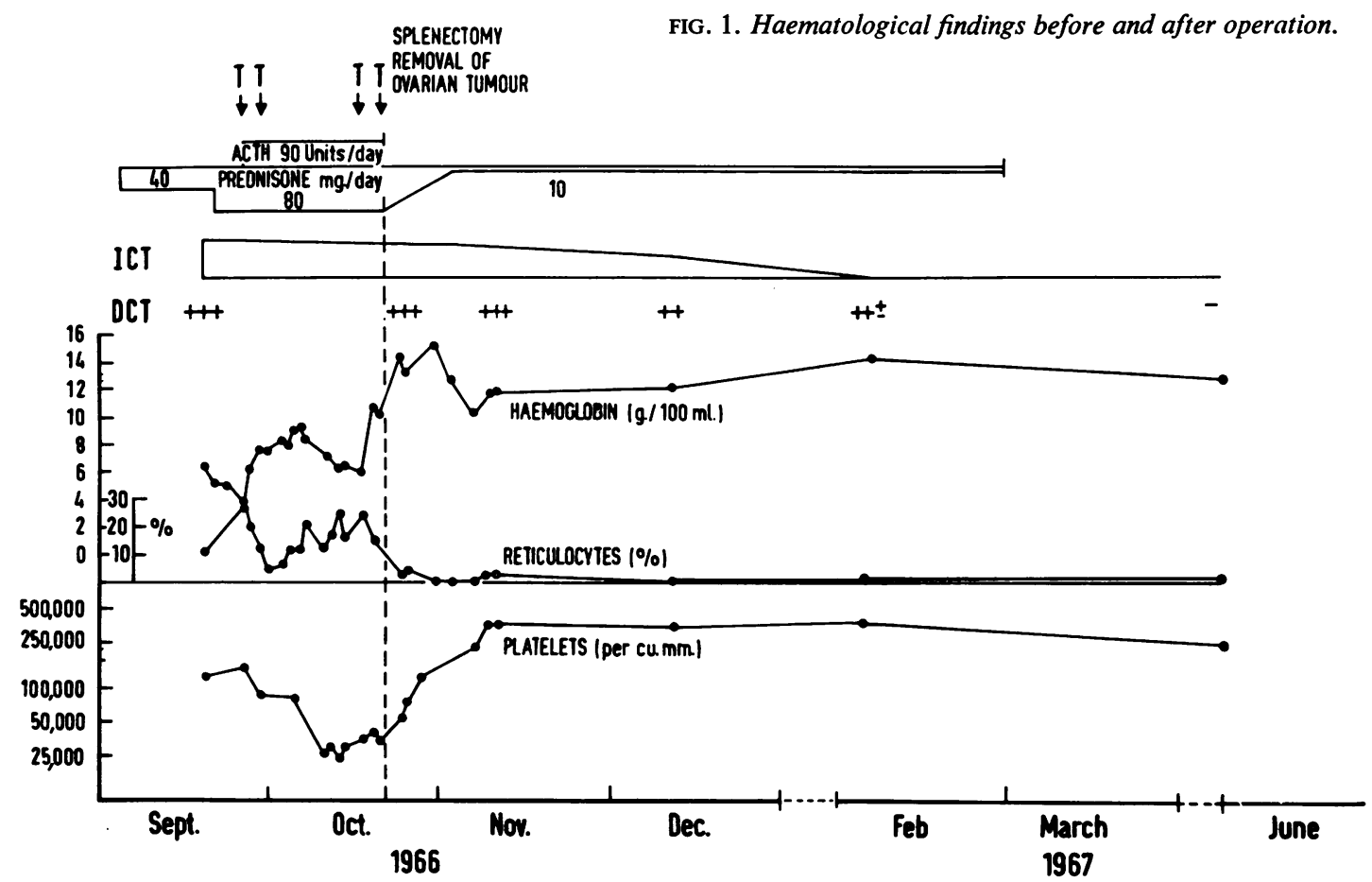

the fact that studies with ${ }^{51} \mathrm{Cr}$-labelled red cells had suggested that this procedure would be of only limited benefit.

On the 36th day of admission (21 October 1966) the spleen was removed (Mr J. Spencer). An unexpected finding was a left ovarian cyst and a smaller fimbrial cyst. The left ovary and tube were excised.

A dramatic and sustained haematological response followed operation (Fig. 1). The haemoglobin level, which had been restored to normal by preoperative blood transfusion, was maintained and the reticulocyte count fell to normal. The platelet count rose after operation. Three weeks after operation the serum bilirubin level was $0.5 \mathrm{mg}$ per $100 \mathrm{ml}$ and no spherocytes could be seen in the peripheral blood film. The ACTH was discontinued immediately after operation and a rapid reduction in the dosage of prednisone was possible. The patient has remained in full haematological remission for one year since operation.

\section{PATHOLOGICAL FINDINGS}

The macroscopic appearances of the spleen and left ovary and fallopian tube are shown in Figure 2.

SPLEEN The spleen weighed $170 \mathrm{~g}$ and measured $12 \times 8.5 \times 2 \mathrm{~cm}$. The surface was smooth and the cut surface was deep red with visible but not especially prominent Malpighian bodies.

Microscopically, the pulp was intensely congested and there was a small amount of stainable iron. Numerous small foci of haemopoiesis were present in the pulp and primitive blood cells were present in the sinuses. The lymphoid follicles were rather widely separated; they were of average size for the age of the patient, had slightly irregular edges,

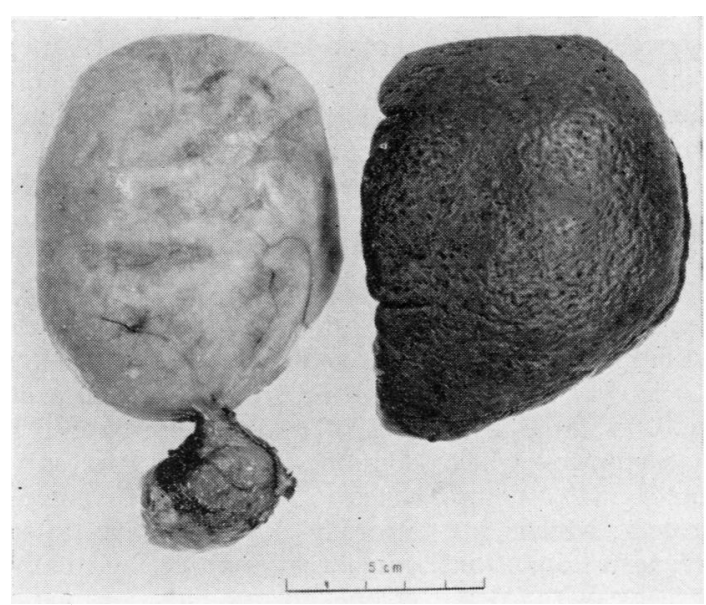

FIG. 2. Macroscopic appearance of spleen and left ovary and tube. The smaller mass is a papillary serous cystadenoma, the larger one a benign cystic teratoma. 
and were composed mostly of lymphoblast-like cells, with very occasional large reticulum cells. There was no separation into perifollicular envelope and follicle, the Malpighian bodies being composed more or less entirely of cells of the type usually present in perifollicular envelopes. Arteriolar changes were consistent with the age of the patient. Other structures were normal.

LEFT OVARY AND FALLOPIAN TUBE The specimen consisted of two ovoid cystic masses connected by a fibrous stalk, $1.7 \mathrm{~cm}$ long, with a $4.3 \mathrm{~cm}$ length of fallopian tube stretched over the surface of the smaller mass. The larger mass $(14 \times 8.5 \times 3.5 \mathrm{~cm})$ was firm, had a smooth surface and, on cutting, had a single cavity containing thick, pale yellow material with some hairs embedded in the centre. The wall was $0.2 \mathrm{~cm}$ thick, had a smooth lining with one firm, yellowish, raised area, $4 \mathrm{~cm}$ diameter, raised 0.5 to $0.8 \mathrm{~cm}$; a few translucent bluish-white areas were visible in this plaque; no hairs were attached to it. The smaller mass $(4.5 \times 3.5 \times 2.8 \mathrm{~cm})$ contained a single cavity filled with coagulated pale, greenish-yellow, gelatinous material and had a wall $0.1 \mathrm{~cm}$ thick. The lining was smooth except for two firm, white, papillary nodules, 0.4 and $0.3 \mathrm{~cm}$ diameter, respectively.

Microscopically, the small mass was a papillary serous cystadenoma. Fifteen blocks from the larger mass showed a benign cystic teratoma of the ovary containing respiratory mucosa with associated seromucous glands; cartilage and smooth muscle; small plaques of bone, one related to bronchial cartilage; largely non-keratinized, stratified squamous mucosa merging with respiratory epithelium; a little keratinized squamous epithelium without associated cutaneous appendages; adipose tissue; glial tissue partly in contiguity with respiratory epithelium; a few nerve bundles and ganglia. No thymic, lymph nodal, or splenic tissue was present.

The respiratory mucosa was infiltrated extensively by a narrow band of lymphoid cells which sometimes mingled with the bronchial glands and also extended into adjacent adipose tissue. The gland ducts were slightly dilated and filled with inspissated eosinophilic mucin. A striking feature in many blocks was the presence in the bronchial mucosa of small or large aggregates of eosinophilic, granular macrophages which contained at least two substances: (1) a neutral mucopolysaccharide or mucoprotein which was strongly PAS positive after glycogen digestion, mucicarminophilic, virtually negative with Alcian green and not metachromatic with toluidine blue; (2) a pigment of lipofuscin type which reduced ammoniacal silver nitrate, was strongly acid-fast, and stained deeply with Sudan black B in paraffin sections. This lipofuscin might 은 have originated from extravasated blood, but the absence of haemosiderin makes it more likely that it had its origin in stagnant lipid contents of a different derivation.

\section{SEROLOGICAL FINDINGS}

Serological findings before and after operation on 21 October 1966 are shown in Table I. Within four

TABLE I

SEROLOGICAL FINDINGS

\begin{tabular}{lccc} 
Date & $\begin{array}{l}\text { Direct Coombs Test } \\
\text { Score at Optimum } \\
\text { Dilution }\end{array}$ & Indirect & $\begin{array}{l}\text { Titre of Incomplete } \\
\text { Antibody against } \\
\text { Enzyme-treated Cells }\end{array}$ \\
\hline 19.9 .66 & 3 & $4 \frac{1}{2}$ & 1,024 \\
25.10 .66 & 3 & 4 & 256 \\
4.11 .66 & 3 & 4 & 128 \\
11.11 .66 & 3 & $2 \frac{1}{2}$ & 64 \\
12.12 .66 & 2 & Negative & 16 \\
7.2 .67 & $2 \frac{1}{2}$ & Negative & 2 \\
1.6 .67 & Negative & &
\end{tabular}

days of operation, the titre of serum incomplete antibody against papainized cells had fallen and a $\vec{\emptyset}$ steady fall continued thereafter. Within 10 weeks of $\varnothing$ operation, the indirect Coombs test was negative. The direct Coombs test had become negative within seven months of operation. The fall in titre of serum incomplete antibody following operation (Table I), when plotted on a semi-logarithmic scale against time, shows a half-life of approximately three weeks. The normal half-life of IgG globulin is 15 to 26 days (Schultz and Heremans, 1966). This observation suggests, therefore, that antibody production ceased completely following operation.

\section{DISCUSSION}

The main clinical and haematological findings in the 14 previously recorded cases of haemolytic anaemia associated with ovarian 'dermoid' cysts, 은 together with the eventual outcome in these cases, $\supset$ are summarized in Table II.

In seven of the cases, removal of the tumour alone, without splenectomy, was performed (Alli- $\sigma$ bone and Collins, 1951; Wuhrmann, 1954; André, N Dreyfus, and Salmon, 1955; Barry and Crosby, N 1957; Szirmai (case 3), 1961; Larrain, Del Solar, 우 and Vargas Molinare, 1963; McAndrew, 1964). Haemolysis ceased in every case.

In three cases (West-Watson and Young, 1938; von Müller and Schubothe, 1958 and Szirmai case 0 2,1961 ), splenectomy did not reduce haemolysis but cure followed subsequent removal of the ovarian $\mathbb{D}$ tumour. In two cases (Singer and Dameshek, 1941; 
TABLE II

DATA FROM CASE REPORTS OF HAEMOLYTIC ANAEMIA ASSOCIATED WITH OVARIAN 'DERMOID' CYSTS'

\begin{tabular}{|c|c|c|c|c|c|c|c|}
\hline Author & $\begin{array}{l}\text { Age } \\
\text { in } \\
\text { Years }\end{array}$ & $\begin{array}{l}\text { Spleno- } \\
\text { megaly }\end{array}$ & $\begin{array}{l}\text { Palpable } \\
\text { Tumour }\end{array}$ & $\begin{array}{l}\text { Haemo- } \\
\text { globin } \\
(g \text { per } \\
100 \mathrm{ml})\end{array}$ & $\begin{array}{l}\text { Reticulo- } \\
\text { cytes }(\%)\end{array}$ & $\begin{array}{l}\text { Auto- } \\
\text { antibody }\end{array}$ & Outcome \\
\hline $\begin{array}{l}\text { West-Watson and Young } \\
\text { (1938) }\end{array}$ & 44 & .. & + & 3.6 & $45 \cdot 5$ & + & $\begin{array}{l}\text { Splenectomy without remission; } 13 \text { weeks } \\
\text { later, ovarian cystectomy performed with } \\
\text { dramatic, complete recovery }\end{array}$ \\
\hline $\begin{array}{l}\text { Singer and Dameshek } \\
\text { (1941) }\end{array}$ & 47 & + & + & $5 \cdot 1$ & 46 & .. & $\begin{array}{l}\text { Short remission after splenectomy; com- } \\
\text { plete recovery after ovarian cystectomy } \\
\text { performed six weeks later }\end{array}$ \\
\hline Lindeboom (1950) & 40 & + & + & $4 \cdot 3$ & 16 & + & $\begin{array}{l}\text { No remission after splenectomy; emergency } \\
\text { surgery for intestinal obstruction due to } \\
\text { teratoma; died at operation }\end{array}$ \\
\hline $\begin{array}{l}\text { Allibone and Collins } \\
\text { (1951) }\end{array}$ & 4 & . & + & 7 & 39 & 0 & $\begin{array}{l}\text { Complete sustained haematological recovery } \\
\text { within three days of ovarian cystectomy; } \\
\text { splenectomy not performed }\end{array}$ \\
\hline $\begin{array}{l}\text { de Gruchy } \\
\text { (1954) }\end{array}$ & 61 & 0 & 0 & $5 \cdot 2$ & 20 & . & $\begin{array}{l}\text { Died of transfusion reaction; normal } \\
\text { spleen and benign ovarian teratoma at } \\
\text { necropsy }\end{array}$ \\
\hline $\begin{array}{l}\text { Wuhrmann } \\
\text { (1954) }\end{array}$ & 53 & 0 & . & $6 \cdot 5$ & 78 & + & $\begin{array}{l}\text { No response to cortisone, ACTH, or nitrogen } \\
\text { mustard; dramatic response to ovarian } \\
\text { cystectomy, with disappearance of auto- } \\
\text { antibody; splenectomy not performed }\end{array}$ \\
\hline $\begin{array}{l}\text { André, Dreyfus, and Salmon } \\
\text { (1955) }\end{array}$ & 54 & $\mathbf{0}$ & + & $\begin{array}{l}\text { PCV } \\
23 \%\end{array}$ & 58 & + & $\begin{array}{l}\text { No response to cortisone; recovery after } \\
\text { bilateral ovarian cystectomy, with disappear- } \\
\text { ance of autoantibody; splenectomy not } \\
\text { performed }\end{array}$ \\
\hline $\begin{array}{l}\text { Procházka } \\
\text { (1956) }\end{array}$ & 40 & + & . & $4 \cdot 3$ & 74 & + & $\begin{array}{l}\text { Possible partial response to ACTH; short } \\
\text { remission after splenectomy; full recovery } \\
\text { after ovarian cystectomy, with disappearance } \\
\text { of auntoantibody }\end{array}$ \\
\hline $\begin{array}{l}\text { Barry and Crosby } \\
\text { (1957) }\end{array}$ & 26 & + & + & $3 \cdot 6$ & 58 & + & $\begin{array}{l}\text { Recovery within seven weeks of ovarian } \\
\text { cystectomy; direct Coombs test still positive } \\
\text { seven weeks after operation; splenectomy not } \\
\text { performed }\end{array}$ \\
\hline $\begin{array}{l}\text { von Müller and Schubothe } \\
\text { (1958) }\end{array}$ & 44 & + & + & 4 & 50 & + & $\begin{array}{l}\text { No response to cortisone, } \mathrm{ACTH} \text {, or } \\
\text { splenectomy; immediate response to ovarian } \\
\text { cystectomy }\end{array}$ \\
\hline $\begin{array}{l}\text { Szirmai (case 2) } \\
\text { (1961) }\end{array}$ & 49 & $\cdots$ & .. & . & . & + & $\begin{array}{l}\text { No response to cortisone, ACTH, or } \\
\text { splenectomy; recovery, with disappearance } \\
\text { of autoantibody, after ovarian cystectomy; } \\
\text { 'chocolate cyst' of ovary and small uterine } \\
\text { myoma also excised }\end{array}$ \\
\hline $\begin{array}{l}\text { Szirmai (case 3) } \\
\text { (1961) }\end{array}$ & 45 & . & + & . & . & + & $\begin{array}{l}\text { Recovery, with disappearance of auto- } \\
\text { antibody, after ovarian cystectomy; splenec- } \\
\text { tomy not performed }\end{array}$ \\
\hline $\begin{array}{l}\text { Larrain, Del Solar, and } \\
\text { Vargas Molnare } \\
\text { (1963) }\end{array}$ & 30 & + & + & $3 \cdot 5$ & $74 \cdot 2$ & + & $\begin{array}{l}\text { Partial response to prednisone, } 60 \mathrm{mg} \text { daily; } \\
\text { complete recovery after cystectomy; splenec- } \\
\text { tomy not performed sustained remission after } \\
\text { ovarian cystectomy; splenectomy not performed }\end{array}$ \\
\hline $\begin{array}{l}\text { McAndrew } \\
\text { (1964) }\end{array}$ & 48 & + & + & 4,2 & 97 & 0 & $\begin{array}{l}\text { No response to prednisone, } 60 \mathrm{mg} \text { daily; } \\
\text { sustained remission after ovarian cystectomy; } \\
\text { splenectomy not performed }\end{array}$ \\
\hline Present case & 52 & 0 & 0 & $6 \cdot 8$ & 11 & + & $\begin{array}{l}\text { No response to prednisone, } 80 \mathrm{mg} \text { daily, } \\
\text { or to ACTH; complete recovery after splenec- } \\
\text { tomy and ovarian cystectomy, with disap- } \\
\text { pearance of autoantibody }\end{array}$ \\
\hline
\end{tabular}

$+=$ present $0=$ absent $\ldots=$ no information

${ }^{1}$ This table is an extension of that of Barry and Crosby (1957).

Procházka, 1956), splenectomy led to a temporary remission with subsequent relapse which was followed by complete remission after ovarian cystectomy.

Response to ACTH and corticosteroids in these patients was generally disappointing (Wuhrmann, 1954; von Müller and Schubothe, 1958; Szirmai (case 2), 1961; McAndrew, 1964) although some response to ACTH and prednisone respectively may have occurred in two cases (Procházka, 1956;
Larrain et al, 1963). In Wuhrmann's (1954) case, nitrogen mustard therapy did not influence haemolysis.

Haemolytic anaemia has also been described in association with non-teratomatous cysts of the ovary, as in the cases of Watson (1939) ('nonspecific cyst'), Jones and Tillman (1945) (pseudomucinous cystadenocarcinoma), and Heeres (1960) (pseudomucinous cystadenoma). In all three cases, 
autoantibodies were demonstrated. In the first case, ovarian cystectomy produced no response but subsequent splenectomy was followed by improvement. In the latter two cases, haemolysis ceased after removal of the ovarian tumour, splenectomy not being performed.

In two cases, the precise histological nature of the ovarian tumour was undetermined (von Miescher, von Reckenberg, Berger, and Holländer, 1958; Szirmai (case 1), 1961). In both cases, haemolysis ceased after ovarian cystectomy. Splenectomy was not performed.

Non-ovarian cysts have also been described in association with haemolytic anaemia in the cases of Velasco Suarez and Angel Etcheverry (1937) (benign cystic teratoma attached to splenic pedicle) and of Sandøe (1953) ('degenerated mesenteric cyst').

In some cases, disappearance of autoantibody has been documented following excision of an ovarian 'dermoid' cyst (André et al, 1955; Procházka, 1956; Szirmai (cases 2 and 3), 1961). In the case of Barry and Crosby (1957), the direct Coombs test remained positive seven weeks after operation. In the cases of von Miescher et al (1958), Heeres (1960), and Szirmai (case 1) (1961), autoantibody eventually disappeared following cystectomy.

In the case we report it seems highly probable that cure was a consequence of the ovarian 'dermoid' cyst being removed, rather than of splenectomy, since studies using ${ }^{51} \mathrm{Cr}$-labelled red cells indicated that the spleen was of limited importance in the destruction of red cells, suggesting that splenectomy would not be followed by major benefit (de Gruchy, 1964). The rapid and complete disappearance of autoantibody following operation further supports this view.

The mechanism by which the production of antibody is provoked in these cases is unknown. One or more of a number of pathogenetic mechanisms could be responsible. One possibility is the production of red cell antibody by the ovarian tumour, providing it is immunologically competent. No antibodies were demonstrated in the tissues or contents of the cysts in the cases of Allibone and Collins (1951), André et al (1955), and von Müller and Schubothe (1958). In the case of Sandøe (1953), a high concentration of antibody was demonstrated in the fluid from a mesenteric cyst; the exact histological nature of the cyst was uncertain. Alternatively, the cyst or its contents may contain material antigenic to the host stimulating the production of antibody which crossreacts with host erythrocytes. A further possiblity is that substances might be liberated by the cyst which alter the red cell surface and render it antigenic to the host. The prominence of mucin and lipofuscin-containing macrophages as an indicator of release of lipids and mucin into the stroma of the cyst in our case may possibly be relevant in this context.

In the case reported here, the rate of fall of antibody titre following operation suggests that antibody production ceased immediately after removal of the ovarian cyst. Although this finding corroborates the suggested cause-effect relationship between the ovarian cyst and antibody production, it does not provide evidence as to the mechanism by which this occurs.

Ovarian teratomata are relatively common, comprising more than $10 \%$ of all ovarian tumours (Evans, 1966). The incidence of haemolytic anaemia is in patients with these tumours is, obviously, low, and we have at present no knowledge as to why a very occasional tumour produces this reaction whilst the vast majority do not. The importance of recognizing the association, despite its rarity, hinges on the excellent prognosis in such cases following ovarian cystectomy. Since the age incidence of the association in cases reported in the literature ranges from 4 to 54 years, the possible existence of this association should be considered in all female patients with autoimmune haemolytic anaemia.

We wish to thank Professor J. V. Dacie for his advice in the preparation of this paper, Mrs P. Lisamore and Mrs J. Farndon for their skilled technical assistance, and Miss E. J. Townsend for her help in preparing the manuscript.

\section{REFERENCES}

Allibone, E. C., and Collins, D. H. (1951). J. clin. Path., 4, 412. André, R., Dreyfus, B., and Salmon, C. (1955). Bull. Soc. med. Hôp. Paris, 71, 1062.

Barry, K. G., and Crosby, W. H. (1957). Ann. intern. Med., 47, 1002. de Gruchy, C. C. (1954). Aust. Ann. Med., 3, 106.

Evans, R. W. (1966). Histological Appearances of Tumours, 2nd ed., p. 657. Livingstone, Edinburgh and London.

Heeres, P. A. (1960). Sem. Hop. Paris, 36, 1411.

Jones, E., and Tillman, C. (1945). J. Amer. med Ass., 128, 1225.

Larrain, C., del Solar, A., and Vargas Molinare, R. (1963). Sangre $\bigcirc$ (Barcelona), 8, 31.

Lindeboom, G. A. (1950). Acta. haemat. (Basel), 4, 343.

McAndrew, G. M. (1964). Brit. med. J., 2, 1307.

Prochazka, J. (1956). Vaitrai Lek., 2, 240.

Sandøe, E. (1953). Nord. Med., 50, 1565.

Schultz, H. E and Heremans, J. F. (1966). Molecular Biology of Human Proteins, vol. 1, p. 476. Elsevier, Amsterdam.

Singer, K., and Dameshek, W. (1941). Ann. intern. Med., 15, 544.

Suarez, C. V., and Etcheverry, M. A. (1937). Arch. argent. Enferm. W Apar. dig., 12, 168.

Szirmai, E. (1961). Wein. Z. inn. Med., 42, 320.

von Miescher, P., von Rechenberg, H. K., Berger, J., and Holländer, L. (1958). Schweiz. med. Wschr., 88, 498.

von Müller, W., and Schubothe, H. (1958). Folia haemat. (Frankfurt), 吕 2, 321 .

Watson, C. J. (1939). Brit. med. J., 12, 1782.

West-Watson, W. N., and Young, C. J. (1938). Brit. med. J., 1, 1305.

Wuhrmann, F. (1954). Bull. schweiz. Akad. med. Wiss., 10, 180. 